Correction

\title{
Correction: Galešić, M., et al. New Screening Tool for Obtaining Concentration Statistics of Pollution Generated by Rivers in Estuaries. Water 2018, 10, 639
}

\author{
Morena Galešić ${ }^{1, * \mathbb{D}}$, Roko Andričević ${ }^{1}$, Vladimir Divić $^{1}$ and Robert Šakić Trogrlić $^{2}$ \\ 1 Faculty of Civil Engineering, Architecture and Geodesy, University of Split, 21000 Split, Croatia; \\ rokoand@gradst.hr (R.A.); vdivic@gradst.hr (V.D.) \\ 2 School of Energy, Geoscience, Infrastructure and Environment, Institute for Infrastructure and Environment, \\ Heriot-Watt University, Edinburgh EH14 4AS, UK; rs36@hw.ac.uk \\ * Correspondence: mgalesic@gradst.hr; Tel.: +385-95-564-0784
}

Received: 26 September 2018; Accepted: 27 September 2018; Published: 29 September 2018

The authors wish to make the following correction to their paper [1]:

The author's name "Robert Šakić Troglić" should be "Robert Šakić Trogrlić".

The authors would like to apologize for any inconvenience caused to the readers by this change. The manuscript will be updated and the original will remain online on the article webpage, with a reference to this Correction.

\section{Reference}

1. Galešić, M.; Andričević, R.; Divić, V.; Šakić Trogrlić, R. New Screening tool for Obtaining Concentration Statistics of Pollution Generated by Rivers in Estuaries. Water 2018, 10, 639. [CrossRef]

(C) 2018 by the authors. Licensee MDPI, Basel, Switzerland. This article is an open access article distributed under the terms and conditions of the Creative Commons Attribution (CC BY) license (http://creativecommons.org/licenses/by/4.0/). 